\title{
BUDGETARY IMPLICATIONS WHEN USING ELECTRONIC TRANSACTIONS IN THE ROMANIAN PUBLIC SECTOR
}

\author{
Nicolae Carmen, carmen.nicolae@orniss.ro \\ National Registry Office for Classified Information,
}

Abstract: The scope and complexity of the financial operations carried out in the public sector justify the investments for the modernization of the means and instruments used for cashing budgetary revenues and for making payments out of public funds.

The implementation of new electronic means must be performed in all the segments of the public sector, but particularly in the treasury units.

The large-scale use of electronic transfers leads to budgetary shifting both in incomes and in expenses. The impact is different and will be analyzed further on.

The budgets of the public entities feel the effects of this shifting in the modification of incomes and expenses. The benefits thus obtained will positively affect the macroeconomic ratios and will finally generate an improvement in the social welfare.

As regards the income, the results must be positive because electronic transactions set the premises for a better raise of the budgetary incomes. The main effects on the income of public entities after the participation in electronic transactions are the following:

1. Positive effects on the public entities' income following the participation in electronic transactions:

1. a better raise because:

- tax payers can inform themselves more accurately about the charges, taxes and contributions they owe;

- tax payers may better comply with the falling due for taxes because the time needed for the payment of such tax liabilities is considerably reduced as the travel to the fiscal body is no more necessary;

- fiscal record will be harder and more accurate;

- tax evasion will be more reduced;

- cross checks will be easier to carry out.

2. higher budgetary income because:

- public services will develop together with the increase of afferent cash, as some public services will be provided online in electronic format (for example e-learning university courses);

- public services will develop together with the increase of afferent cash, as more people will find out about the offer of public entities;

- investments made in the public sector for the implementation of electronic systems will generate supplementary income for VAT, income tax, custom duties, etc.

- self-financed activities of the treasury connected with the development of the portfolio of electronic products will generate income from commissions and from the short-term money investment.

As regards the expenses, the budgetary implications of using electronic payment instruments are more complex because:

- they entail structural budgetary shifting;

- they generate savings for certain categories of expenses;

- they encourage public investments. 
The effects of using electronic cash and payment technologies are synthesized taking into consideration the target budget and the aimed expense items.

2. Effects of the use of electronic cash and payment technologies on the expenses of the budgets that are components of the unitary system of public budgets:

- expenses with the personnel employed at pay desks are severely reduced as there is a decrease in the cash and payment activities. Such decrease in the number of personnel will be felt particularly in the treasury units and, to a smaller extent, in the public entities;

- expenses with the commission paid at the Romanian Post for sending home the rights payable from the state budget (allowances, incentives, benefits) are lower;

- expenses with the daily allowance for job-delegated personnel are lower;

- at the same time, the costs for ensuring archive storage conditions to the documents in proof are reduced;

- maintenance costs for the pay desks locations are lower;

State budget:

- investments in the IT and modernization of equipment increase;

- the number of positions for IT workers increases, thus reducing unemployment;

- expenses with the personnel employed at pay desks are lowered as there is a decrease in the cash and payment activities. If departments for tax payments and local charges are established, the reductions will be operated in these departments;

- there will be reductions with the personnel raising taxes on site (for example parking charges);

- maintenance costs for pay desks locations will be reduced;

- fuel expenses will be reduced because of the fewer situations when the original documents (especially the payment orders) must arrive at the treasury unit (most of the times located in another city).

Local budget:

- investments in the IT and modernization of equipment increase;

- the number of positions for IT workers increases, thus reducing unemployment.

State social insurance budget:

reduced;

- expenses with the personnel in the regional pension houses and offices will be

- expenses for the commissions paid to the Romanian Post for home delivery of the rights payable from the state social insurance budget (pensions) will lower;

- expenses for the postal dispatch of the annual individual score of the employees will be reduced.

Budget of the unique national health social insurance fund:

- expenses for the personnel employed in the regional health offices, CASAOPSNAJ and CASMTCT will be reduced.

Budget of the unemployment insurance:

- expenses for the personnel employed as cashiers will lower in all regional employment agencies;

- expenses for the commission of the Romanian Post for home dispatch of the rights payable from the unemployment insurance budget (doles).

Budget of state treasury:

- costs for cash handling (implying cash withdrawal commissions payable by the National Bank of Romania, as well as the transport and transport security) will be reduced;

- costs for the coverage of loses associated with operational risk will

Budget of subsidized public entities:

- expenses for the personnel employed as cashiers will be significantly lowered following a reduction of cashing and cash paying activities; 
- costs for archive storage of documents in proof will be reduced.

Budget of self-financed public entities:

- expenses for the personnel employed as cashiers will be significantly lowered following a reduction of cashing and cash paying activities;

- costs for archive storage of documents in proof will be lowered.

\section{Budgetary effects of using electronic cash and payment technologies from the viewpoint of expenses items and paragraphs:}

- expenses with the salaries of the cashiers will lower due to the reduction in the number of employed cashiers. The decrease of pay desk operations may lead to a decrease in the paid overtime period following the big quantity of work;

- expenses with the daily allowance for job-delegated personnel to other cities are lower;

Cash salary expenses:

- expenses with the salaries of IT qualified personnel increase;

Salary expenses in nature:

- the number of dinner tickets for the employed personnel will be adjusted (for public entities empowered to grant such tickets);

Contributions to social insurance:

- contributions to the social insurance will change directly with the modification of cash salaries expenses;

Fuels and lubricants:

- fuel consumption for journeys of public entities representatives to the treasury entity for cash deposits/withdrawals will lower concurrently with the significant decrease of cashimplying operations;

- fuel used up for cash transport to and from treasury units is reduced by using cash to a smaller extend.

Post Office, Telecommunications, Radio, Television, Internet:

- expenses with telecommunication and Internet will rise following the use of services that require phone lines and connection platforms to Internet: POS in cash desks, home-banking, Internet-banking.

Non-life insurance premiums:

- the decrease in cash payments and receipts entails significant reductions in the insurance expenses during transportation;

Service rendering for rights' demise:

- together with the generalization of transfers, expenses borne from the budget for the payment of home-dispatched social welfare rights will decrease significantly.

Interests of public debts:

- the use of electronic transactions allows for a better administration of the public funds, reducing the need for long-term loans and the interests afferent to such loans.

Fixed assets:

- implementation of new technologies brings about an increase in the expenses for equipment purchase.

The budgetary effects of using electronic means are substantial and lead to modifications both in the increase of certain categories of expenses and in the decrease of others. If we compare the two tendencies we notice that the decreases in expenses are more significant, and this is a positive aspect. These effects generate structural modifications, meaning that the current expenses are lowered and the position of capital expenses is consolidated. We think the modifications generated are beneficial to the public system and are meant to consolidate the public sector finance. 


\section{Conclusions}

As regards public entities, the terminals for electronic transfer must be introduced if there is a demand for them (or at least there is a high potential). The electronic means must be chosen so as to offer maximum facilities under the assumed cost conditions.

There is a variety of parameters that are considered when establishing the implementation strategy of new technologies:

- existence of card issuers in localities;

- banking culture of the population;

- number of IT experts that can be recruited;

- categories of income collected by public entities;

- alternative variants for collecting the income;

- categories of expenses provided in the budgets of public entities;

- the volume of cash expenses;

- categories of traditional agents that public entities work with (for example the Romanian Post);

- methods of alternative payment that may be used.

The implementation of new technologies shall be done gradually (while a firm correlation with the budgetary allowances exists) and closely connected with the local potential (as regards the experts, and those who will use these new technologies).

As regards the state treasury, we think that a wide range of services based on technologies that allow for rapid and low-cost electronic transfers must be developed. Lately, important steps have been made to this end (the electronic payment was implemented, universal product code readers were introduced, etc.), but this trend of modernizing the state treasury services must be carried on.

We suggest that the services offered by the state treasury also include:

- payment orders by which more taxes included in the predefined vectors can be paid;

- $\quad$ banking cards issued under an international logo;

- owner-type banking cards;

- teller machines for cash withdrawals;

- banking transfer automatic machines;

- cash banking automatic machines;

- POS in own pay desks;

- home-banking;

- internet-banking;

- secured payment platforms similar to those of e-commerce.

The budgetary impact of the measures previously described is an important one, with effects on all budgets that are components of the unitary system of public budgets. The same effects, analyzed on the economic structure of expenses, generate structural modifications because certain categories of expenses are reduced while others increase.

We think the modifications generated are beneficial to the public system and are meant to consolidate the public sector finance.

At an international level, platforms, systems, devices and means for rendering more efficient the electronic transactions have been developed. In Romania, the financial-banking system was the one that started implementing such technological resources in order to improve the service rendering quality. This led to making natural and legal persons more sensitive as regards the facilities offered and stimulated them to resort to them. From the public sector's viewpoint, we must highlight three essential aspects that will help us to better define the connections between the public and the private sector as regards this subject: 
- the facilities offered by the electronic platforms, systems, devices and means may have a positive impact on the financial activity of the public sector;

- the natural and legal persons are to a great extend (if not completely) tax payers and are often in a position to pay amounts to the budget;

- the natural and legal persons may benefit, under the provisions of the law, from certain amounts from the budget (as budgetary assisted or employed).

Romanian budgetary sector has a great potential. The financial flows that make up the public financial resources and allot them have a significant weight in economy. Analyzing the general consolidated budget one notices that over a third of the gross internal product is directed to one of the budgets component of the unitary system of public budgets. Also, the equivalent of 35\% of the gross internal product is allotted from the budgetary funds in salaries, taxes, social assistance rights, purchase payments (consumer goods, inventory objects, equipment, other investments, etc.).

Analyzing the conduct of public entities in Romania we may conclude that:

1. Payment of salaries is effected by card transfer to a very small extend. At least in cities and towns where there are possibilities for cash withdrawal, the compulsory banking card transfer should be imposed.

2. Several social assistance rights are paid in cash although their beneficiaries have/would like to have banking cards (scholarships, allowances for the new-born babies).

3. Payment of small value goods and services is made cash, thinking that banking transfer is not justified.

4. Payments made decentralized are, to a greater extend, in cash than payments made based on aggregate information from the territory.

5. For occasional payments, cash is preferable, and for the rhythmical payments we come, more frequently, across databases with the beneficiaries' accounts.

Analyzing the impact of economic transactions as regards public entities, we think that, for better meeting the current requirements, these transactions should ensure the cashing of incomes and the making of payments by means of the following electronic platforms, devices and systems:

- POS and manual printers;

- E-tax platforms connected to home-banking and Internet-banking applications;

- Platforms for the management of payments initiated by SMSs;

- Automatic transfer machines;

- Automatic cash machines

We recommend that the public system initiate the implementation of electronic platforms, systems, devices and means that are part of the supply portfolio of commercial banks because in this way we have a higher degree of usage. The more a platform, system, device or means is familiar to the bank clients, the greater the success of their usage will be if they are implemented in public entities as well.

As regards the public sector, steps were made for the implementation of new technologies that allow for electronic transactions. We think that the current approaches sustaining the modernization of public entities and state treasury should be encouraged. Moreover, we think that the state treasury should make itself conspicuous as a prestigious financial institution in the Romanian economic background.

\section{Bibliography}

1. Anderson Linda - "Paper or Plastic? Society becomes more 'Cashless"”, AgNews, January 2005;

2. Anderson Ross - "Why Cryptosystems Fail, Computer and Comm. Security", USA, 1993;

3. Ayadi Achraf - "Technological and organizational preconditions to Internet Banking implementation: Case of a Tunisian bank", Journal of Internet Banking and Commerce, April 2006; 
4. Corrocher Nicoletta - "Does Internet banking substitute traditional banking? Empirical evidence from Italy", CESPRI - Centro di Ricerca sui Processi di Innovazione e Internazionalizzazione, November 2002;

5. György Attila - "Acceptance of the acquis communautaire in Romanian banking sector", Challenges to the Financial Sectors in Candidate / Acceding Countries in the Context of the Internal Market Acquis, Editor Economic Policy Institute, Sofia (Bulgaria) 2005;

6. György Attila - "Advertisement - an Institutional Way to develop the Financial Sector in Romania" published in Financial Sectors Development in Central and Eastern European Countries and EU Integration, Editor Economic Policy Institute, Sofia (Bulgaria) 2005;

7. György Attila - "Implementarea sistemului electronic de plăți la Trezoreria Statului" published in "Educație şi instruire" (Volumul V), Editor Universității Naţionale de Apărare Carol I, Bucharest 2006;

8. György Attila - "Local Tax and Fee Payment Using Cards in Romania" published in "The proceedings of the International Economic Conference „25 Years of Higher Economic Education in Braşov" - Editor Infomarket, Braşov 2005;

9. György Attila - "Plata electronică a impozitelor şi taxelor instituţiilor publice din România între obligativitate şi lipsă de interes" published in "Finanțele şi dezvoltarea durabilă", Editor ASE, Bucharest 2004;

10. György Attila - "Public Finance and European Integration" - The Reform of Public Administration in the Context of European Integration, Editor Cavallioti, Bucharest 2006;

11. Haynes Michelle şi Thompson Steve - "The Productivity Impact of IT Deployment: an Empirical Evaluation of ATM Introduction", Discussion Papers in Economics (University of Nottingham), August 2000;

12. Kraan Dirk-Jan - "Budgetary Decisions - A Public Choice Approach", Editor University Press, Cambridge 1996;

13. Mustgrave Richard şi Musgrave Peggy - "Public Finance in Theory and Practice" (Forth Edition) - Editor McGraw Hill, New York 1984;

14. Nishimukai K. - "Reform of Clearing System in Japan”, ISSA, Seul, October 2005;

15. www.americanexpress.com

16. www.avoconsult.ro

17. www.bis.org

18. www.bnro.ro

19. www.clr.ro

20. www.ecb.int

21. www.efinance.ro 